\title{
PENGARUH MODEL PEMBELAJARAN PROBLEM BASED LEARNING UNTUK MENINGKATKAN HASIL BELAJAR SISWA PADA MATERI POKOK CAHAYA DI KELAS VIII SMP SWASTA ASSISI MEDAN T.A. 2013/2014
}

\author{
Paian Tamba dan Motlan \\ paiantamba@gmail.com \\ Jurusan Fisika FMIPA Universitas Negeri Medan \\ Jalan Willem Iskandar Pasar V Medan, 20221
}

\begin{abstract}
ABSTRAK
Penelitian ini bertujuan untuk mengetahui pengaruh model pembelajaran Problem Based Learning untuk meningkatkan hasil belajar siswa pada materi pokok cahaya di kelas VIII SMP Swasta Assisi Medan T.A. 2013/2014. Jenis penelitian ini adalah kuasi eksperimen. Populasi dalam penelitian adalah seluruh siswa kelas VIII Semester II SMP Swasta Assisi Medan yang terdiri dari 4 kelas berjumlah 145 orang. Pengambilan sampel dilakukan dengan cara cluster random sampling dengan mengambil 2 kelas dari 4 kelas secara acak yaitu kelas VIII-4 sebagai kelas eksperimen yang berjumlah 35 orang dan kelas VIII3 sebagai kelas kontrol yang masing-masing berjumlah 35 orang. Instrumen yang digunakan untuk mengetahui hasil belajar siswa adalah tes hasil belajar dalam bentuk pilihan berganda dengan jumlah 15 soal dan aktivitas siswa dengan menggunakan lembar observasi yang dilakukan oleh dua observer. Dari hasil penelitian diperoleh nilai ratarata pretes kelas eksperimen 30.5 dan nilai rata-rata pretes kelas kontrol 29.3. Berdasarkan hasil postes, diperoleh bahwa rata-rata kelas eksperimen 68.9 dan kelas kontrol 60.4. Rata-rata nilai keseluruhan aktivitas belajar siswa adalah 61.43 termasuk dalam kriteria aktif. Hasil uji t menunjukkan bahwa ada pengaruh model pembelajaran Problem Based Learning untuk meningkatkan hasil belajar siswa pada materi pokok cahaya di kelas VIII SMP Swasta Assisi Medan T.A. 2013/2014.
\end{abstract}

\section{Kata kunci : Aktivitas, Hasil Belajar, Problem Based Learning}

\section{PENDAHULUAN}

Pendidikan adalah suatu proses dalam rangka mempengaruhi siswa agar dapat menyesuaikan diri sebaik mungkin terhadap lingkungannya, dengan demikian akan menimbulkan perubahan dalam dirinya yang memungkinkan untuk berfungsi dalam kehidupan masyarakat. Ilmu Pengetahuan
Alam (IPA) adalah salah satu mata pelajaran yang dipelajari dalam pendidikan formal dan juga termasuk ke dalam mata pelajaran yang di-UN-kan untuk tingkat Sekolah Menengah Pertama (SMP) dan Sekolah Menengah Atas (SMA). Hal ini menempatkan mata pelajaran fisika sebagai salah satu pelajaran yang penting untuk 
dipelajari. Bidang studi fisika sebagai bagian dari IPA merupakan objek mata pelajaran yang menarik dan lebih banyak memerlukan pemahaman dari pada penghafalan. Berdasarkan pengalaman penulis saat melakukan Program Pengalaman Lapangan Terpadu (PPLT), bahwa dalam kegiatan belajar mengajar siswa selalu diberikan teori-teori dan cara menyelesaikan soal-soal fisika tanpa mengarahkan siswa untuk membawa konsep fisika dalam kehidupan sehari-hari. Hal tersebut menyebabkan siswa menjadi tidak aktif dan kreatif sehingga pelajaran fisika menjadi membosankan dan menjadi salah satu pelajaran yang sulit dipelajari dan tidak disukai oleh siswa.

Berdasarkan hasil wawancara yang dilakukan pada guru fisika di SMP Swasta Assisi Medan, mengungkapkan bahwa hasil belajar fisika siswa masih rendah, dimana hasil belajar fisika siswa kelas VIII dalam Ujian Akhir Semester Genap pada T.A. 2010/2011 rata-rata 50, pada T.A. 2011/2012 rata-rata 56 dan pada T.A. 2012/2013 rata-rata 54 sedangkan Kriteria Ketuntasan Minimal (KKM) yang akan dicapai adalah 60. Sehingga dapat dikatakan nilai rata-rata siswa tidak mencapai kriteria yang diharapkan. Hal ini relevan dengan data yang diperoleh dari instrumen angket yang disebarkan kepada 36 siswa, diperoleh bahwa 38,89\% siswa menyatakan bahwa fisika sulit dan kurang menarik, 27,78 \% siswa menyatakan bahwa fisika di kelas itu biasa saja, $11,11 \quad \%$ siswa menyatakan fisika mudah dan menyenangkan, dan 22,22 \% siswa menyatakan fisika membosankan.
Berdasarkan hasil observasi di SMP Swasta Assisi Medan, proses pembelajaran yang terjadi masih konvensional dan berpusat pada guru dan siswa hanya pasif, kurang ada respon berupa pertanyaan maupun argumen ataupun minta penjelasan ulang. Siswa lebih sering hanya diberikan rumus-rumus yang siap pakai tanpa memahami makna dari rumus-rumus tersebut. Siswa sudah terbiasa menjawab pertanyaan dengan prosedur rutin, sehingga ketika diberikan masalah maka siswa akan kebingungan.

Salah satu alternatif yang dapat digunakan untuk mengatasi masalah tersebut adalah dengan model pembelajaran Problem Based Learning (model pembelajaran berdasarkan masalah). Model pembelajaran ini dirancang dengan tujuan untuk membantu siswa mengembangkan kemampuan berfikir dan mengembangkan kemampuan dalam memecahkan masalah.

Menurut hasil penelitian Efriandi (2013) diperoleh hasil pembelajaran berdasarkan masalah cukup baik, dimana nilai rata-rata siswa dikelas eksperimen (menggunakan model pembelajaran berdasarkan masalah) meningkat dari 40,38 menjadi 71,28. Hasil nilai rata-rata aktivitas siswa selama pembelajaran menggunakan pembelajaran berdasarkan masalah di kelas eksperimen dari pertemuan pertama diperoleh nilai rata-rata aktivitasnya 70\% (kategori cukup) pertemuan kedua nilai rata-rata aktivitasnya 80\% (kategori baik) dan pada pertemuan ketiga nilai ratarata aktivitasnya $85 \%$ (kategori sangat baik). 


\section{METODE PENELITIAN}

Penelitian ini dilaksanakan di SMP Swasta Assisi Medan pada semester genap T.A. 2013/2014. Waktu penelitian dilaksanakan pada bulan Maret - April 2014. Sampel dalam penelitian ini terdiri dari dua kelas yang dipilih secara acak dengan teknik cluster random sampling, dimana satu kelas sebagai kelas eksperimen (kelas yang menerapkan model pembelajaran problem based learning) yakni kelas VIII-4 dan satu kelas lagi sebagai kelas kontrol (kelas yang menerapkan pembelajaran konvensional) yakni kelas VIII-3.

Instrumen dalam penelitian ini adalah tes hasil belajar dan lembar observasi. Tes yang digunakan untuk memperoleh data hasil belajar siswa terdiri dari dua bagian, yaitu: tes untuk pretes dan tes untuk postes yang diberikan kepada siswa. Adapun tes yang diberikan berupa tes pilihan berganda sebanyak 15 soal, masingmasing soal mempunyai 4 option. Tes ini disusun berdasarkan analisis kurikulum KTSP, buku pegangan guru dan siswa. Sebelum tes digunakan terlebih dahulu dilakukan validitas isi oleh tiga orang validator yaitu dua orang dosen fisika Unimed dan seorang guru fisika. Lembar Observasi dimaksudkan untuk mengamati keseluruhan aktivitas belajar siswa selama pelaksanaan proses pembelajaran.

Penelitian ini termasuk jenis penelitian kuasi eksperimen.

Prosedur penelitian adalah tahap-tahap dan kegiatan tindakan yang dilakukan dalam proses penelitian sesuai tujuan yang ingin dicapai. Adapun tahap-tahap dalam penelitian ini meliputi :
1. Tahap persiapan

a. Menyusun jadwal penelitian.

b. Meminta izin kepada pihak sekolah perihal kegiatan penelitian yang akan dilakukan di SMP Swasta Assisi Medan.

c. Melakukan observasi langsung dengan memberikan angket kepada siswa dan wawancara pada guru fisika di SMP Swasta Assisi Medan.

d. Menyiapkan instrumen pengumpulan data yang akan digunakan dalam penelitian, antara lain lembar wawancara, lembar angket, lembar observasi aktivitas siswa, dan tes hasil belajar.

e. Pencarian pustaka yang relevan.

f. Mengadakan konsultasi dengan dosen pembimbing skripsi.

g. Menyusunan proposal penelitian.

h. Mempersiapkan materi pembelajaran sebagai panduan penelitian dalam proses pencapaian tujuan yang diinginkan.

i. Menyusun RPP.

j. Menyusun instrumen soal tes untuk memperoleh data tentang hasil belajar siswa.

2. Tahap pelaksanaan

a. Menentukan kelas sampel dari populasi yang ada.

b. Melaksanakan pre-tes untuk mengetahui hasil belajar siswa dan untuk mendapatkan data awal pada kelas eksperimen dan kontrol.

c. Menentukan kelas eksperimen dan kelas kontrol penelitian dengan melakukan analisis data pre-tes yaitu uji normalitas (untuk mengetahui sampel berdistribusi normal atau tidak) 
dan uji $\mathrm{t}$ dua pihak (untuk mengetahui kesamaan pengetahuan awal sampel) pada kedua kelas sampel.

d. Melakukan pengajaran fisika pada kedua kelas, kelas eksperimen menggunakan model pembelajaran Problem Based Learning dan kelas kontrol menggunakan model pembelajaran konvensional

e. Mengamati aktivitas pada proses pembelajaran baik kelas eksperimen maupun kelas kontrol.

f. Memberikan pos-tes kepada kedua kelas untuk mengetahui hasil belajar siswa setelah materi selesai diajarkan.

3. Tahap Pengumpulan Data

Langkah-langkah yang ditempuh dalam pengolahan data adalah:

a. Mentabulasi data yang berhubungan dengan tes hasil belajar fisika siswa dari dua kelas yaitu kelas eksperimen dan kelas kontrol.

b. Mencari nilai rata-rata dan simpangan baku dari kedua kelas tersebut.

c. Pemeriksaan uji normalitas data.

d. Pemeriksaan uji homogenitas varians.

e. Pemeriksaan uji hipotesis penelitian.

f. Menarik kesimpulan.

\section{HASIL PENELITIAN DAN PEMBAHASAN}

\section{Hasil Penelitian}

Pada tahapan penelitian, kedua kelas sampel yaitu kelas eksperimen dan kelas kontrol diberikan pretes sebagai syarat awal penelitian yang bertujuan untuk melihat kemampuan awal belajar siswa pada kedua kelas tersebut.

Setelah dilakukan pretes, pada kelas eksperimen diperoleh rata-rata 30,5. Demikian halnya dengan kelas kontrol setelah pretes diperoleh ratarata 29,3 . Untuk melihat secara rinci hasil pretes kedua kelas dapat dilihat pada Gambar 1.

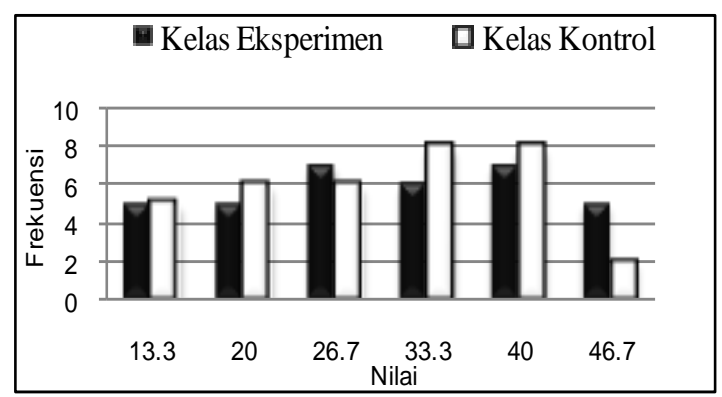

Gambar 1. Diagram Batang data pretes kelas eksperimen dan kelas kontrol

Setelah dilakukan pengajaran, kedua kelas sampel yaitu kelas eksperimen dan kelas kontrol diberikan postes yang bertujuan untuk melihat kemampuan akhir belajar siswa.

Setelah dilakukan postes, pada kelas eksperimen diperoleh rata-rata 68,9. Demikian halnya pada kelas kontrol, diperoleh ratarata 60,4 . Untuk melihat secara rinci hasil pretes kedua kelas dapat dilihat pada Gambar 2. 


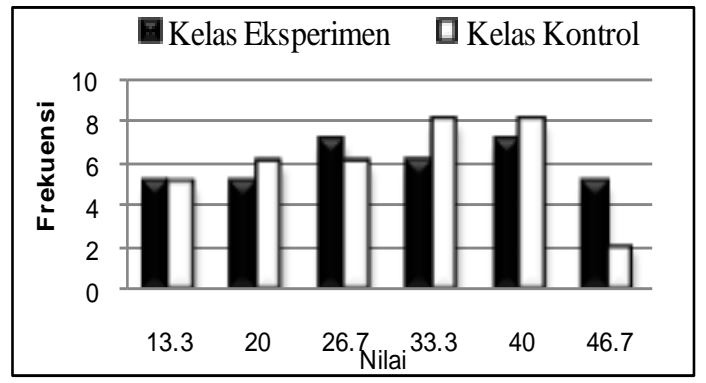

Gambar 2. Diagram Batang data postes kelas eksperimen dan kelas kontrol

\begin{tabular}{lcr}
\multicolumn{2}{c}{ Perbandingan } & kemampuan \\
kognitif & siswa & berdasarkan \\
taksonomi & Bloom yang memiliki \\
beberapa & tingkat kemampuan \\
ditunjukkan pada Tabel 1 dan Tabel &
\end{tabular}

Tabel 1. Skor rata-rata kemampuan kognitif siswa pada pretes berdasarkan taksonomi Bloom

\begin{tabular}{|l|c|c|c|c|}
\hline \multirow{2}{*}{ Kelas } & \multicolumn{4}{|c|}{ Skor rata-rata siswa } \\
\cline { 2 - 5 } & $\mathrm{C}_{3}$ & $\mathrm{C}_{4}$ & $\mathrm{C}_{5}$ & $\mathrm{C}_{6}$ \\
\hline Eksperimen & 11,33 & 10,71 & 10,67 & 9,5 \\
\hline Kontrol & 11 & 10,43 & 10,33 & 8,5 \\
\hline
\end{tabular}

Data pada Tabel 1 dapat ditampilkan dalam bentuk diagram seperti ditunjukkan pada Gambar 3.

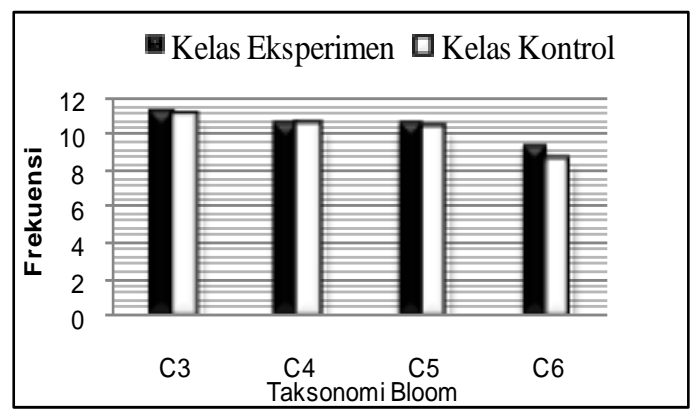

Gambar 3. Diagram batang Skor rata-rata kemampuan kognitif siswa pada pretes berdasarkan taksonomi bloom
Berdasarkan Gambar 3, ratarata skor kognitif siswa pada $\mathrm{C}_{3}$ (pengetahuan) adalah kemampuan yang paling banyak diperoleh siswa.

Tabel 2. Skor rata-rata kemampuan kognitif siswa pada postes berdasarkan taksonomi Bloom

\begin{tabular}{|l|c|c|c|c|}
\hline \multirow{2}{*}{ Kelas } & \multicolumn{4}{|c|}{ Skor rata-rata siswa } \\
\cline { 2 - 5 } & C3 & C4 & C5 & C6 \\
\hline Eksperimen & 23,33 & 25,14 & 23,67 & 22,5 \\
\hline Kontrol & 21 & 21,14 & 21 & 21,5 \\
\hline
\end{tabular}

Data pada tabel 2 dapat ditampilkan dalam bentuk diagram seperti ditunjukkan pada Gambar 4.

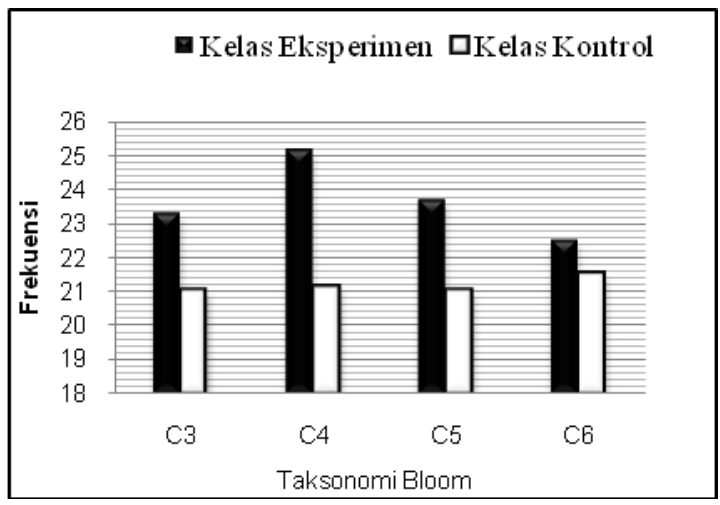

Gambar 4. Diagram batang Skor rata-rata kemampuan kognitif siswa pada postes berdasarkan taksonomi Bloom

Berdasarkan Gambar 4 dapat diketahui bahwa kemampuan kognitif siswa di kelas eksperimen menggunakan model pembelajaran Problem Based Learning lebih tinggi daripada kemampuan kognitif siswa di kelas kontrol.

Uji normalitas data pretes dan postes kelas eksperimen dan kelas kontrol digunakan untuk mengetahui apakah data pretes dan postes berdistribusi normal. Uji normalitas dilakukan dengan menggunakan uji Liliefors. Hasil uji 
normalitas data pretes dan postes kedua kelas dinyatakan dalam Tabel 3 .

Tabel 3. Hasil Uji Normalitas Kelas Eksperimen dan Kelas Kontrol

\begin{tabular}{|c|c|c|c|c|}
\hline \multirow{2}{*}{ Kelas } & \multicolumn{2}{|c|}{ Data Pretes } & \multicolumn{2}{c|}{ Data Postes } \\
\cline { 2 - 5 } & Lhitung & Ltabel & Lhitung & Ltabel \\
\hline Eksperime & 0,122 & 0,149 & 0,132 & 0,149 \\
$\mathrm{n}$ & 5 & 7 & 2 & 7 \\
\hline \multirow{2}{*}{ Kontrol } & 0,135 & 0,149 & 0,122 & 0,149 \\
& 5 & 7 & 1 & 7 \\
\hline
\end{tabular}

Pada taraf signifikan $\alpha=0,05$ dan $\mathrm{n}$ $=35$ diperoleh harga $L_{\text {uble }}=0,1497$, dengan demikian pada kelas eksperimen dan kontrol $L_{\text {ubel }}>L_{\text {hitung }}$, maka dapat disimpulkan bahwa data dari kedua sampel berasal dari populasi yang berdistribusi normal.

Uji homogenitas dilakukan untuk mengetahui apakah data pretes dan postes kelas eksperimen dan kelas kontrol homogen. Pengujian homogenitas data pretes dan postes kelas eksperimen dan kelas kontrol dilakukan dengan uji kesamaan dua varians. Untuk selengkapnya hasil uji homogenitas data pretes dan postes kedua kelas dinyatakan dalam Tabel 4.

Tabel 4. Ringkasan Hasil Uji

Homogenitas Kedua Kelas

\begin{tabular}{|c|c|c|c|}
\hline Data & $F_{\text {hitung }}$ & $F_{\text {tabel }}$ & Kesimpulan \\
\hline Pretes & 1,18 & 1,76 & Homogen \\
\hline Postes & 1,13 & 1,76 & Homogen \\
\hline
\end{tabular}

\section{Pengujian}

hipotesis kemampuan postes dilakukan dengan uji $\mathrm{t}$ dengan tujuan untuk mengetahui perbedaan hasil belajar siswa yang diajar dengan model pembelajaran Problem based Learning dan yang diajar dengan pembelajaran konvensional pada materi pokok cahaya dikelas VIII semester genap SMP Swasta Assisi Medan T.A. 2013/2014. Berdasarkan hasil uji hipotesis data postes, diperoleh bahwa thitung $>t_{\text {tabel }}$ yaitu 4,450>1,668 maka $\mathrm{H}_{0}$ ditolak dan $\mathrm{Ha}$ diterima. Dapat disimpulkan bahwa ada perbedaan hasil belajar siswa akibat pengaruh model pembelajaran Problem Based Learning dengan pembelajaran Konvensional pada materi pokok cahaya di kelas VIII semester genap SMP Swasta Assisi Medan T.A. 2013/2014.

Observasi bertujuan untuk mengamati aktivitas belajar siswa selama pembelajaran dengan model pembelajaran Problem Based Learning. Observasi dilakukan selama kegiatan belajar mengajar yang terdiri dari tiga kali pertemuan. Perkembangan aktivitas siswa di kelas eksperimen mengalami peningkatan selama menerima pembelajaran dengan model pembelajaran Problem Based Learning. Perkembangan aktivitas siswa di kelas eksperimen ditunjukkan pada Gambar 5.

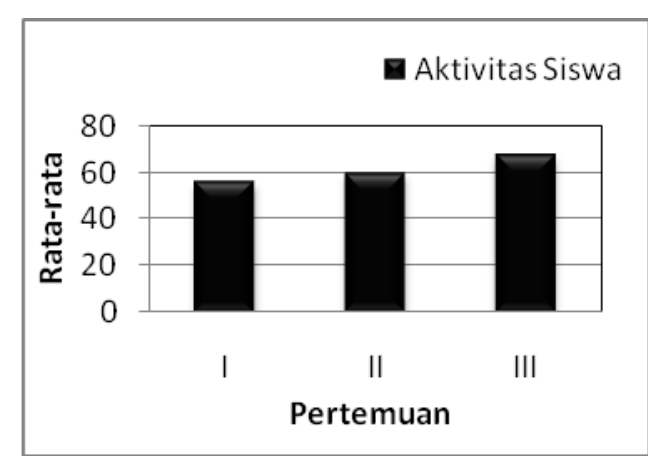

Gambar 5. Diagram batang aktivitas siswa

Berdasarkan Gambar 5, ratarata aktivitas siswa pada pertemuan I adalah 56.03, pada pertemuan II 
diperoleh rata-rata aktivitas 60.16, dan pada pertemuan III diperoleh rata-rata aktivitas

68.10 . Peningkatan aktivitas belajar siswa dari pertemuan I sampai pertemuan III dengan rata-rata nilai seluruhnya adalah 61.43 dengan kriteria penilaian aktif.

\section{Pembahasan Hasil Penelitian}

Hasil penelitian menunjukkan bahwa ada pengaruh menggunakan model pembelajaran Problem Based Learning untuk meningkatkan hasil belajar fisika siswa pada materi pokok cahaya di Kelas VIII Semester Genap SMP Swasta Assisi Medan. Hal ini diperkuat dengan perolehan nilai rata-rata pretes siswa di kelas eksperimen sebesar 30,5 dengan standar deviasi 11,01 dan nilai ratarata postes sebesar 68,9 dengan standar deviasi 7,74. Sedangkan di kelas kontrol diperoleh nilai ratarata pretes siswa sebesar 29,3 dengan standar deviasi 10,13 dan nilai rata-rata postes sebesar 60,4 dengan standar deviasi 8,20, dan diperoleh thitung $>t_{\text {tabel }}=(4,450>$ 1,668) maka dapat disimpulkan bahwa $\mathrm{H}_{0}$ ditolak dan $\mathrm{H}_{\mathrm{a}}$ diterima.

Berdasarkan data nilai pretest dan postest beserta nilai aktivitas belajar siswa pada kelas eksperimen diperoleh bahwa siswa yang memiliki kriteria pretes sangat kurang, kriteria aktivitas aktif dan kriteria postes baik (SKAB) berjumlah 13 siswa (37,15\%); siswa yang memiliki kriteria pretes sangat kurang, kriteria aktivitas aktif dan kriteria postes cukup (SKAC) berjumlah 7 siswa (20\%); siswa yang memiliki kriteria pretes sangat kurang, kriteria aktivitas aktif dan kriteria postes kurang (SKAK) berjumlah 1 siswa $(2,86 \%)$; siswa yang memiliki kriteria pretes sangat kurang, kriteria aktivitas cukup aktif dan kriteria postes baik (SKCAB) berjumlah 4 siswa (11,42\%); siswa yang memiliki kriteria pretes sangat kurang, kriteria aktivitas aktif dan kriteria postes baik (SKCAC) berjumlah 9 siswa $(25,71 \%)$; dan siswa yang memiliki kriteria pretes sangat kurang, kriteria aktivitas cukup aktif dan kriteria postes kurang (SKCAK) berjumlah 1 siswa $(2,86 \%)$. Data nilai pretest dan postest beserta nilai aktivitas belajar siswa pada kelas eksperimen dapat ditampilkan dalam bentuk diagram seperti ditunjukkan pada Gambar 6 .

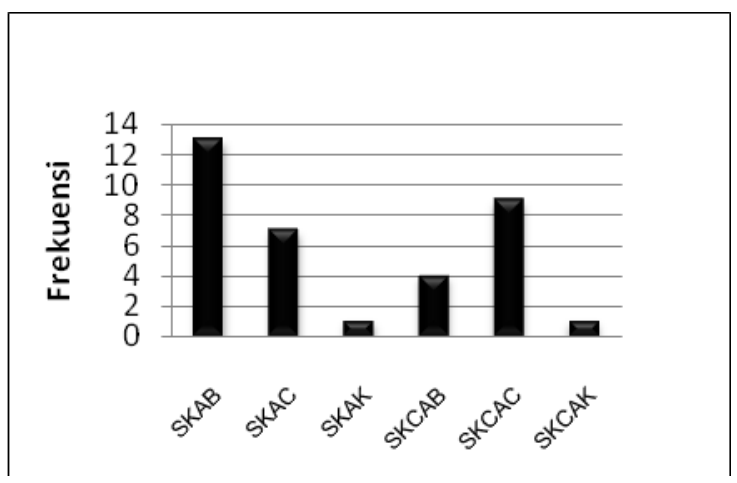

Gambar 6. Diagram batang kategori nilai pretes, aktivitas dan postes

Kelebihan yang dapat
diberikan dalam penelitian menggunakan model pembelajaran Problem Based Learning ini adalah meningkatkan kemampuan siswa dalam pemecahan masalah dan menjadi pebelajar yang otonom dan mandiri.

pembelajaran model pembelajaran Problem Based Learning mendorong siswa untuk lebih aktif di dalam kelas. Misalnya pada saat mengerjakan LKS, siswa dibagi ke dalam kelompok yang hanya beranggotakan 5 sampai 6 
orang siswa, mengerjakan LKS selama 30 menit, kemudian mempresentasikan hasil diskusi kepada teman-teman yang lain. Hal ini mendorong siswa untuk lebih berpartisipasi dalam kerja kelompoknya.

\section{KESIMPULAN DAN SARAN Kesimpulan}

Berdasarkan hasil penelitian dan pembahasan, maka simpulan dari penelitian ini adalah: (1) Hasil belajar siswa pada materi pokok cahaya dengan menggunakan model pembelajaran Problem Based Learning di kelas VIII SMP Swasta Assisi Medan Semester Genap T.A. 2013/2014 memiliki rata-rata 68,9 dalam kategori cukup baik. (2) Hasil belajar siswa pada materi pokok cahaya dengan menggunakan pembelajaran konvensional di kelas VIII SMP Swasta Assisi Medan Semester Genap T.A. 2013/2014 memiliki rata-rata 60,4 dalam kategori cukup baik. (3) Ada perbedaan hasil belajar siswa akibat pengaruh model pembelajaran Problem Based Learning dengan pembelajaran Konvensional pada materi pokok cahaya di kelas VIII SMP Swasta Assisi Medan Semester Genap T.A. 2013/2014, dengan thitung $=4,450>\mathrm{t}_{\text {tabel }}=1,668$. (4) Aktivitas belajar siswa dengan menggunakan model pembelajaran Problem Based Learning memiliki rata-rata 61,43 dengan kategori aktif.

\section{Saran}

Bagi guru bidang studi fisika di SMP Swasta Assisi Medan agar berkenan mencoba menggunakan model pembelajaran Problem Based Learning dalam melaksanakan kegiatan pembelajaran sebagai salah satu alternatif untuk meningkatkan hasil belajar siswa.

\section{DAFTAR PUSTAKA}

Arends, R.I., (2008), Learning To Teach, Penerbit Pustaka Belajar, Yogyakarta.

Arikunto, S., (2006), Prosedur Penelitian Suatu Pendekatan Praktik, Penerbit Bumi Aksara, Jakarta.

Djamarah, Z., (2006), Strategi Belajar Mengajar, Penerbit Rineka Cipta, Jakarta.

Novi, E., (2013), Pengaruh Model Pembelajaran Berdasarkan Masalah pada Materi Pokok Tekanan di Kelas VIII Semester II SMP PAB 2 Helvetia Medan, Skripsi, FMIPA Unimed, Medan.

Rusman, (2010), Model-Model Pembelajaran, Penerbit Rajagrafindo Persada, Jakarta.

Sagala, S., (2009), Konsep dan Makna Pembelajaran, Penerbit Alfabeta, Bandung.

Sardiman, (2010), Interaksi dan motivasi Belajar Mengajar, Penerbit Rajawali Pers, Jakarta.

Slameto, (2003), Belajar dan Faktorfaktor yang Mempengaruhinya, Penerbit Rineka Cipta, Jakarta.

Sudjana, (2005), Metode Statistika, Penerbit Tarsito, Bandung.

Sudjana, N., (2009), Penilaian Hasil Proses Belajar Mengajar, PT Remaja Rosdakarya, Bandung.

Trianto, (2010), Mendesain Model Pembelajaran Inovatif Progresif, Penerbit Kencana, Jakarta. 